\title{
Psoriasis Treatment Changes the Expression Profile of Selected Caspases and their Regulatory MicroRNAs
}

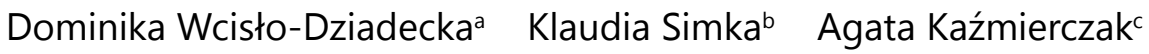 \\ Celina Kruszniewska-Rajsc Joanna Golac Beniamin Grabarekc \\ Jolanta Hybiak $^{d} \quad$ Catherine Grillon $^{\mathrm{e}} \quad$ Urszula Mazurek $^{c}$ Marek J. Łos ${ }^{\mathrm{e}, \mathrm{f}}$
}

aDepartment of Skin Structural Studies, Chair of Cosmetology, School of Pharmacy with the Division of Laboratory Medicine in Sosnowiec, Medical University of Silesia, Katowice, ${ }^{b}$ Department of Internal Medicine, School of Public Health in Bytom, Medical University of Silesia, Katowice, 'Department of Molecular Biology, School of Pharmacy with the Division of Laboratory Medicine in Sosnowiec, Medical University of Silesia, Katowice, Poland, dDepartment of Pathology, Pomeranian Medical University, Szczecin, ${ }^{e}$ Centre de Biophysique Moléculaire, Orleans, France, ${ }^{f}$ Małopolska Centre of Biotechnology, Jagiellonian University, Krakow, Poland

\section{Key Words}

adalimumab • Psoriasis $•$ Caspase $\cdot$ Micro-RNA $\cdot$ Inflammosome $\cdot$ Clinical $•$ Humira $・$ Exemptia

\begin{abstract}
Background/Aims: Psoriasis, an autoimmune diseases of the skin, characterized by patches of abnormal/inflammed skin, although not usually life-threatening, it causes severe discomfort, esthetic impairments, and may lead to impaired social functions and social withdrawal. Besides UV-phototherapy, various anti-inflammatory treatments are applied, depending on the severity of symptoms. In 2008, adalimumab (fully humanized human anti-TNF antibody) was launched for the treatment of psoriasis. In the quest to better understand the pathomechanism of adalimumab's therapeutic effects, and the acquired resistance to the drug, we have investigated how its administration affect the regulation of the expression of selected caspases, including those activated by inflammosome. Methods: The research was initially carried out on normal human dermal fibroblasts (NHDF) treated with adalimumab for 2, 8 and 24 hours in vitro. Then, expression profile of genes encoding caspases and their regulatory micro-RNAs was determined with the use of oligonucleotide microarray. The validation of the microarray results was carried out by qRT-PCR. The in vitro study was followed by ex-vivo investigation of adalimumab's effects on the expression of caspase- 6 in blood of the psoriatic patients. The samples were collected before, and 2 hours after adalimumab's administration and the analysis was determined by qRT-PCR. Results: The result of the analysis indicated that introduction of adalimumab to the NHDF culture resulted in the change of the transcription activity of genes encoding caspases and genes encoding miRNAs. The analysis revealed 5

\begin{tabular}{ll}
\hline Marek J. Łos & LinkoCare Life Sciences AB \\
& SE-58330 Linköping (Sweden) \\
& Tel. +46-766-531168, E-Mail bioappl@gmail.com
\end{tabular}
\end{abstract}

\section{KARGER}




\section{Cellular Physiology Cell Physiol Biochem 2018;50:525-537 \begin{tabular}{ll|l} 
DOI: 10.1159/000494166 & O 2018 The Author(s). Published by S. Karger AG, Basel \\
www.karger.com/cpb
\end{tabular} \\ Wcisło-Dziadecka et al.: Therapy-Induced Changes of Caspase Expression}

different miRNA molecules regulating the expression of: CASP2, CASP3 and CASP6. There were no statistically significant differences in the expression of gene encoding caspase- 6 in the patients' blood before and 2 hours after the anti-TNF drug administration. Conclusion: We have found that adalimumab administration affects caspases expression, thus they may be used as molecular markers for monitoring the therapy with the use of an anti-TNF drugs, including adalimumab. It is likely that the mechanisms responsible for changed expression profiles of genes encoding caspase-2,-3, and -6 , may be caused by the upregulation of the respective microRNA molecules. Increased expression of genes encoding specific caspases may induce inflammatory processes, as well as trigger apoptosis. Furthermore, the proapoptotic activity of caspases may be enhanced by miRNA molecules, which exhibit proapoptotic function. The overexpression of such miRNAs was observed in our study.

(C) 2018 The Author(s)

Published by S. Karger AG, Basel

\section{Introduction}

Caspases are intracellular proteolytic enzymes, whose normal activity is crucial for maintaining homeostasis in human body. These enzymes belong to the cysteine protease family and are commonly known for their ability to regulate apoptosis, [1, 2] (either at its initiation and execution stages), as well as to induce inflammatory process [3-6]. However, the latest studies prove that caspases also participate in other cellular processes, i.e. proliferation, differentiation, cell migration [7-10] and pyroptosis [11]. Caspases also participate in autophagy [12-14]. The studies show that induction of autophagy may directly trigger apoptosis through caspase activation [15].

So far, 18 various caspases have been found, out of which 13 are present in humans [16]. Depending on the main function, the following pro-inflammatory caspases are distinguished: $-1,-4,-5,-11,-12$ (in mouse and in man, listed together) and proapoptotic ones, which, in turn, can be divided into initiator caspases: $-2,-8,-9,-10$ and effector caspases: $-3,-6,-7[16,17]$. The role of the other caspases is still not clear.

Caspases are generated in the form of inactive precursors - procaspases and require activation in order to form a functional enzyme [18]. Procaspases are formed by N-terminal prodomain and two subunits: a large one marked as p20 (with the mass of about 20kDa) and a small one - p10 (with the mass of about 10kDa). The active form of the enzyme is heterotetramer, formed by two large subunits p20 and two small subunits p10 [18]. Proinflammatory caspases and initiator caspases have long regulatory domains, which are characterized by a structural motive, called death domain (DD), enabling aggregation with other proteins. These caspases are activated within a large protein complexes, for example inflammasome, while recruitment of procaspases to the complexes is possible thanks to a relevant domains: DED (death effector domain) or CARD (caspase recruitment domains) [1921]. Effector caspases have short prodomains and they are activated by initiator caspases [18].

Irregularities in the expression of genes encoding caspases are observed in the course of numerous pathological processes, including, in tumors [22], neurodegenerative and autoimmune diseases [10]. For instance, in psoriatic lesions there occurs overexpression of caspase-5 [23] and irregular activity of caspase-1 is observed in the course of many other pro-inflammatory diseases [10].

Autoimmune diseases, among others, psoriasis, rheumatoid arthritis or inflammatory bowel diseases, pose a serious challenge for contemporary medicine. Incidence of these diseases is still growing. The autoimmune diseases are manifested by chronic inflammatory condition, the etiopathogenesis of which is still not fully known [24]. Hence, lack of good knowledge of etiopathogenesis impairs the development of an effective treatment. However, recent studies of molecular mechanisms in psoriatic patients give a new promise for effective therapy [25-27].

Therapy of autoimmune diseases mainly involves targeting of the underlying inflammatory process. To this end, biologic drugs with anti-TNF effect are used. TNF (tumor 


\section{Cellular Physiology Cell Physiol Biochem 2018;50:525-537

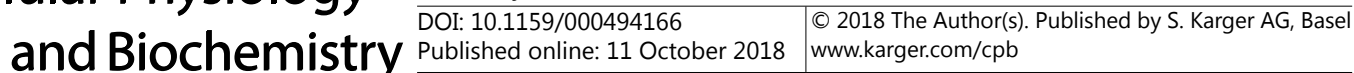 \\ Wcisło-Dziadecka et al.: Therapy-Induced Changes of Caspase Expression}

necrosis factor- $\alpha$ ) plays a crucial role in the pathogenesis of many inflammatory diseases [28]. In the course of psoriasis, it causes keratinocytes activation and their excessive proliferation. It is also responsible for an increased proliferation of T- and B-lymphocytes and differentiation of B-lymphocytes. Blocking of the TNF activity ensures high efficacy of therapy [29]. An example of the biological drug with anti-TNF activity is adalimumab (Humira, Exemptia)- a fully-humanized recombinant monoclonal antibody, generated through expression in the ovarian cells of a Chinese hamster. adalimumab neutralizes the biological effect of TNF by forming complexes with it, hence blocking its ability to engage specific receptors. The anti-TNF therapy is effective, however, it causes some side effects arising mostly from its immunosuppressive functions [30]. Moreover, patients subjected to long-term therapy with the use of anti-TNF drugs, often develop therapy resistance [31].

In order to increase the efficacy of the therapy, it is very important to pinpoint the causes for the loss of patients' response to treatment, as well as to choose a molecular marker(s), which could indicate decreased efficacy of treatment before occurrence of phenotypic symptoms. It would enable to early diagnose the patient's decreasing response to treatment and choose another form of therapy before re-occurrence of the disease symptoms.

Numerous studies have lately shown the potential of microRNAs as diagnostic- and/or prognostic markers. MiRNAs are short (about 23-nucleotide), single-stranded, non-coding fragments of RNA of endogenous origin, which are responsible for regulation of $\sim 1 / 3$ of all human genes [32]. miRNAs expression pattern is tissue-specific. Hence, the level of miRNA expression depends on the tissue, but it is also affected by the cell type, its metabolic state and pathophysiological changes, which occur i.e. during disease [33]. MiRNAs are responsible for negative posttranscriptional regulation of gene expression [34, 35].This is achieved by miRNA's binding to the 3'UTR (untranslated) region of the target transcript. The complementarity of the sequences of these two molecules plays the key role in the said process. There are two possibilities to regulate gene expression through miRNA: (i) transcript degradation and (ii) translation inhibition. One miRNA type may regulate transcription of hundreds of genes, while one gene may be regulated by many types of miRNA molecules [34]. Changes in the expression of genes encoding caspases and miRNAs involved in their regulation after treatment with adalimumab have not been studied so far.

MicroRNAs may constitute highly-specificity and highly-sensitivity markers for ongoing metabolic changes. Moreover, they are stable and resistant to ribonucleases, changes of temperature and $\mathrm{pH}$. They are characterized by high availability and easy acquisition, with simultaneous low invasiveness of miRNA-dependent tests. Furthermore, the miRNA molecule expression may be analyzed with the use of basic molecular biology tools, such as qRT-PCR or oligonucleotide microarray techniques [32]. Results of studies conducted by Hlavaty and colleagues show that diversified response of patients to anti-TNF therapy is connected with caspase-9 polymorphism [36]. Thus, it is possible that the activity of other caspases also correlate with patients' sensitivity to such therapy. Consequently, the study was guided by a hypothesis that a change in transcription activity of genes encoding caspases may be connected with the mechanism of patients' lost response to adalimumab therapy. With regard to the foregoing, the genes encoding caspases and miRNAs regulating their activity could become a molecular markers and/or additional targets in the anti-TNF therapy. The aim of the study was to assess whether the genes encoding caspases, or miRNAs that change their transcription activity are affected by anti-TNF therapy.

\section{Materials and Methods}

Material used for the study

Material used to study expression of genes encoding caspases involved a line of normal human dermal fibroblasts (NHDF) cell line and peripheral blood of the psoriatic patients undergoing the anti-TNF therapy. 


\section{Cellular Physiology Cell Physiol Biochem 2018;50:525-537 \begin{tabular}{l|l} 
and Biochemistry Published 10.1159/000494166 & $\begin{array}{l}\text { (c) } 2018 \text { The Author(s). Published by S. Karger AG, Basel } \\
\text { www.karger.com/cpb }\end{array}$
\end{tabular}}

Wcisło-Dziadecka et al.: Therapy-Induced Changes of Caspase Expression

Cell culture

The NHDF cells (Lonza, Basel, Switzerland) from the $4^{\text {th }}$ passage were cultured at $6 \times 10^{5}$ cells per culture plate (area of $57 \mathrm{~cm}^{2}$ ). The cells were grown for 48 hours in Direct Heat $\mathrm{CO}_{2}$ Incubator(Thermo Fisher Scientific, Waltham, MA, USA) under standard conditions: temp. $37^{\circ} \mathrm{C}$, at humidity of $95 \%$ and $5 \% \mathrm{CO}_{2}$ enriched atmosphere. The dedicated FBM culture medium(Fibroblast Basal Medium; Lonza) was used, with an addition of insulin and gentamicin ( $\mathrm{FGM}^{\mathrm{TM}}$ SingleQuots ${ }^{\mathrm{TM}}$; Lonza). adalimumab, in its final concentration of $8 \mu \mathrm{g} / \mathrm{ml}$ medium was added to the culture. The cells were treated with adalimumab for 2, 8 and 24 hours $(2 \mathrm{H}, 8 \mathrm{H}, 24 \mathrm{H})$.Three biological replicates were performed. The control (C) consisted of normal human dermal fibroblasts, incubated in the same conditions as the tested group, without addition of adalimumab.

\section{Peripheral blood}

Peripheral blood was taken from 8 psoriatic patients, treated with the anti-TNF biological drug adalimumab. The patients took $40 \mathrm{mg}$ of adalimumab in pre-filled syringes every two weeks. Once per 3 months, the patients' had their skin examined and routine blood tests (so-called monitoring) were performed. Two blood samples were taken each time during such monitoring: the first one directly before adalimumab administration and the second one two hours later. Tested samples were taken from various monitoring tests ( $\mathrm{a}$ and b), during which different PASI (Psoriasis Area and Severity Index) values were noted (Table 1).

\section{Cytotoxicity test}

The cytotoxicity of adalimumab in the culture of NHDF cells was evaluated with the use of XTT test (In vitro Toxicology Assay Kit, XTT based; Sigma-Aldrich, St Louis, MO, USA).

\section{Total RNA extraction}

Extraction of total RNA from NHDF was performed with the use of TRIzol@ (Invitrogen Life Technologies, Carlsbad, CA, USA) reagent, according to the producer's protocol. Then RNA was purified with the use of RNeasy Mini Kit (QIAGEN, Hilden, Germany) and DNase I (Fermentas International Inc.,Burlington, ON, Canada). The quantitative and qualitative evaluation of extracts was performed with the use of GeneQuant II (Pharmacia LKB Biochrom Ltd., Cambridge, UK) spectrophotometer and the agarose electrophoresis method. Extraction of total RNA from patient's blood was conducted with the application of the phenolchloroform method, using the Fenozol (A\&A Biotechnology, Gdynia, Poland) reagent. The quantitative and qualitative evaluation of extracts was performed with the use of GeneQuant II (Pharmacia LKB Biochrom Ltd., Cambridge, UK) spectrophotometer and the agarose electrophoresis (not shown).

\section{Oligonucleotide microarray procedure}

Expression profile of genes encoding caspases was determined with the use of oligonucleotide microarray HGU-133A 2.0 (Affymetrix, Santa Clara, CA), according to the producer's protocol. $250 \mathrm{ng}$ of total RNA was used for the procedure. The first stage involved synthesis of cDNA, then the biotinylated RNA was synthesized, purified and fragmented (GeneChip 3'IVT Express Kit, Affymetrix, Santa Clara, CA, USA). RNA hybridization with the microarray was performed for $16 \mathrm{~h}$ in the temperature of $45^{\circ} \mathrm{C}$ at $60 \mathrm{RPM}$ (rotations per minute). The Fluidics Station 450(Affymetrix) and Hybridization Wash and Stain Kit (Affymetrix) were used to stain the microarray with streptavidin-phycoerythrin. The intensity of transcriptome fluorescence was determined with the use of Affymetrix Gene Array Scanner $30007 \mathrm{G}$ and Gene Chip $^{\circledR}$ Command Console ${ }^{\circledR}$ Software (Affymetrix, Santa Clara, CA).

Table 1. PASI values for patients under study observed during various monitoring tests

\begin{tabular}{lccccccccc}
\hline PASI value & & \multicolumn{1}{c}{ Patient } \\
& A & B & C & D & E & F & G & H \\
& & & & & & & & \\
\hline Monitoring a & 21 & 14 & 15 & 18 & 16,9 & 18 & 16 & 1,9 \\
& & & & & & & & \\
Monitoring b & 5 & 5,7 & 5 & 5 & - & 6 & 5 & 1 \\
& & & & & & & & \\
\hline
\end{tabular}




\section{Cellular Physiology Cell Physiol Biochem 2018;50:525-537 \begin{tabular}{l|l|l} 
and Biochemistry & DOI: 10.1159/000494166 & $\begin{array}{l}\text { (c) } 2018 \text { The Author(s). Published by S. Karger AG, Basel } \\
\text { www.karger.com/cpb }\end{array}$
\end{tabular}}

Wcisło-Dziadecka et al.: Therapy-Induced Changes of Caspase Expression

MiRNA microarray procedure

Expression profile of genes encoding microRNA molecules was determined with the use of microarray Gene Chip ${ }^{\circledR}$ miRNA 2.0 Array (Affymetrix), according to the producer's protocol (FlashTag ${ }^{\text {TM }}$ Biotin HSR RNA LabelingKits). 750ng of total RNA was used for the analysis. Evaluation of the staining efficiency was made with the use of ELOSA QC Assay (FlashTagBiotin HSR RNA Labeling Kit; Affymetrix), according to the producer's protocol. RNA hybridization with the microarray was performed for $16 \mathrm{~h}$ in temperature $48^{\circ} \mathrm{C}$ at 60 RPM (rotations per minute). Washing and staining of the microarray were made according to the manufacturer's protocol.

\section{QRT-PCR procedure}

Analysis of the expression of the caspase- 6 encoding gene was performed by qRT-PCR. The CASP6 gene expression in the NHDF $(2 \mathrm{H}, 8 \mathrm{H}, 24 \mathrm{H})$ was identified comparing to the control group. The reaction was conducted with the use of QuantiTect SYBR Green RT-PCR kit (Qiagen, Valencia, CA, USA) and primers with complementary sequences to the tested gene: FH1_CASP6 and RH1_CASP6 (Sigma-Aldrich). The Opticon ${ }^{\mathrm{TM}}$ DNA Engine SequenceDetector (MJ Research Inc., Watertown, MA, USA) was used. Thermal profile of the reaction included reverse transcription $\left(50^{\circ} \mathrm{C}, 30 \mathrm{~min}\right)$, polymerase activation $\left(94^{\circ} \mathrm{C}, 15 \mathrm{~min}\right)$, and then 40 cycles of: denaturation $\left(94^{\circ} \mathrm{C}, 15 \mathrm{~s}\right)$, annealing $\left(60^{\circ} \mathrm{C}, 30 \mathrm{~s}\right)$, extension $\left(72^{\circ} \mathrm{C}, 45 \mathrm{~s}\right)$.

\section{Statistical and bioinformatic analyses}

The comparative analysis covering the results of the oligonucleotide microarray experiment was performed with the use of PL-Grid Infrastructure and GeneSpring 12.6.1 program (Agilent Technologies, Inc., Santa Clara, CA, USA). The statistical analysis of results obtained from miRNA microarray was conducted with the use of miRNAQCTool version 1.1.10 (Affymetrix) and Transcriptome Analysis Console 2.0 (Affymetrix) software. The miRNA molecules that have potential ability to regulate expression of genes encoding caspases were identified in the microRNA database (http://www.microrna.org). The miRandamirSVR algorithm, a combination of the miRanda and mirSVR algorithms, was used to find the relevant miRNA molecules. The statistical analysis of qRT-PCR results was performed with the use of Statistica 12 PL (StatSoft, Tulsa, Oklahoma, USA). $\mathrm{p}<0.05$ was assumed as a level of statistic significance. The statistical analysis of the results comprised the one-way ANOVA test $(\mathrm{p}<0.05)$ and the post-hoc Tukey`s test in order to identify the statistically important differences in the expression of genes encoding caspases, between the groups under study (fibroblasts exposed for 2,8 and $24 \mathrm{~h}$ to adalimumab), compared to the control. In order to identify the statistically important differences in the expression of gene encoding caspase- 6 in the patients' blood before the anti-TFN drug administration and $2 \mathrm{~h}$ after its administration, the Mann-Whitney $\mathrm{U}$ test was conducted.

\section{Results}

Cytotoxicity test

The XTT did not show any cytotoxic activity of adalimumab towards normal human dermal fibroblasts (NHDF), data not shown.

\section{Analysis of expression of genes encoding caspases}

The analysis included assessing the diversity of transcripts in normal human skin fibroblasts (NHDF) exposed to adalimumab by: 2,8 and $24 \mathrm{~h}(2 \mathrm{H}, 8 \mathrm{H}, 24 \mathrm{H})$ compared to the control. The first stage of the differentiation degree assessment was the analysis of the expression profile of the ID mRNA of caspases encoding genes by hierarchical clustering using Euclidean distances. The result of the analysis indicated that introduction of the tested drug to the culture resulted in the change of the transcription activity of genes encoding caspases. The most prominent differences in the expression profile of this set of genes was observed after $2 \mathrm{~h}$ of incubation, whereas, after $24 \mathrm{~h}$ the profile returned almost to the level observed in the control sample (Fig. 1). 


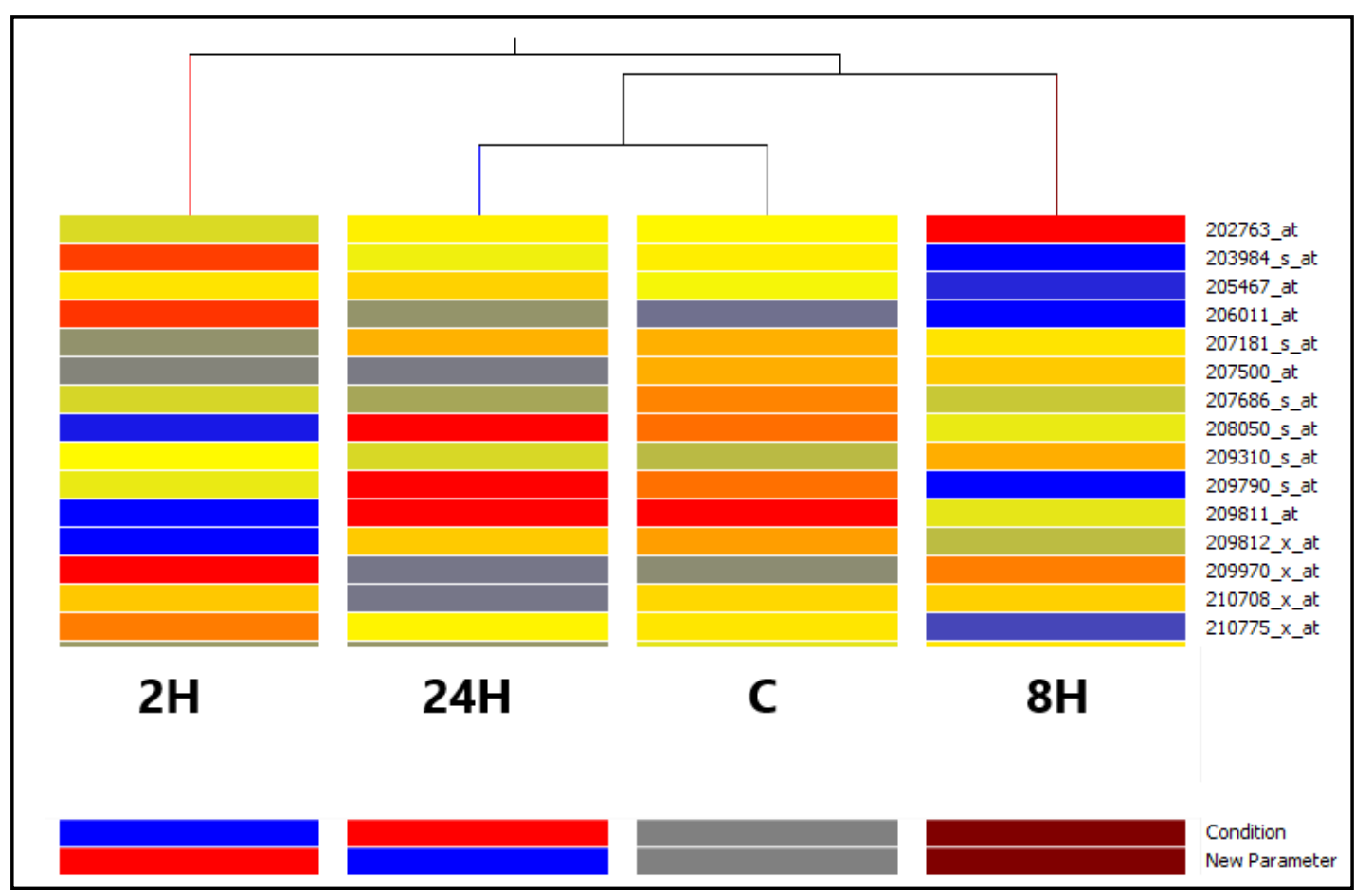

Fig. 1. Hierarchical clusterization of transcriptomes for genes related to caspases in normal human dermal fibroblasts (NHDF), depending on the time of exposure to adalimumab in vitro. C=control (NHDF not treated with adalimumab), $2 \mathrm{H}, 8 \mathrm{H}, 24 \mathrm{H}$ represent respectively: $2 \mathrm{~h}, 8 \mathrm{~h}$, and $24 \mathrm{~h}$ incubation time with adalimumab.

The one-way ANOVA analysis with Benjamini-Hochberg's correction, showed the statistically important differences in the expression of 11transcripts (Table 2 ). The differentiating transcripts corresponded to 6 genes encoding the following caspases: CASP1, CASP2, CASP3, CASP4, CASP6, CASP9. Post-hoc Tukey's test revealed mRNAs differentiating the

Table 2. Quantitative changes in mRNA expression upon challenging NHDF with adalimumab. A) Number of mRNA IDs differentiating transcriptomes of all tested groups, determined with the use of a one-way ANOVA test with BenjaminiHochberg's correction

\begin{tabular}{lccccc}
\hline ID mRNA & $\mathrm{P}<0.05$ & $\mathrm{P}<0.02$ & $\mathrm{P}<0.01$ & $\mathrm{P}<0,0050$ & $\mathrm{P}<0.0010$ \\
\hline 25 & 11 & 10 & 10 & 10 & 8
\end{tabular}
individual transcriptome groups (C, 24H, 8H, 2H) (Table 3). The number of differentiating mRNA IDs depended on the time of exposure to adalimumab. When comparing the average fluorescence signals for $2 \mathrm{H}$ vs $\mathrm{C}$ - 5 differentiating mRNA IDs were identified, for $8 \mathrm{H}$ vs $\mathrm{C}-7$ mRNA IDs, and for $24 \mathrm{H}$ vs $\mathrm{C}-1$ mRNA ID.

A next stage involved evaluation of mRNA ID characteristic for studied groups of transcriptomes $(2 \mathrm{H}, 8 \mathrm{H}$ and $24 \mathrm{H})$ in comparison to control, with the use of Venn diagram (Fig. 2, Table 4). adalimumab administration immediately changed 5 mRNA IDs of caspases, including 4 specific only for $2 \mathrm{H}$, and 1 common for $2 \mathrm{H}$ and $8 \mathrm{H}$. After 8 hours of adalimumab administration - 5 specific

Table 3. Quantitative changes in mRNA expression upon challenging NHDF with adalimumab. mRNAs differentially expressed among studied groups; significance determined with the post-hoc Tukey's test.

\begin{tabular}{lcccc}
\hline \multirow{2}{*}{ Transcriptome group } & \multicolumn{4}{c}{ mRNA } \\
& C & $2 \mathrm{H}$ & $8 \mathrm{H}$ & $24 \mathrm{H}$ \\
\hline $\mathrm{C}$ & 11 & 5 & 7 & 1 \\
$2 \mathrm{H}$ & 6 & 11 & 7 & 6 \\
$8 \mathrm{H}$ & 4 & 4 & 11 & 7 \\
$24 \mathrm{H}$ & 10 & 5 & 4 & 11 \\
\hline
\end{tabular}


Fig. 2. The Venn diagram showing mRNA IDs characteristic for transcriptomes of NHDF exposed to adalimumab in vitro in comparison to control. $\mathrm{C}=$ control, $2 \mathrm{H}, 8 \mathrm{H}$, $24 \mathrm{H}$ represent respectively: 2 $\mathrm{h}, 8 \mathrm{~h}$, and $24 \mathrm{~h}$ incubation time with adalimumab The statistical evaluation was performed with the use of the post-hoc - Tukey's test (Table 4 legend).

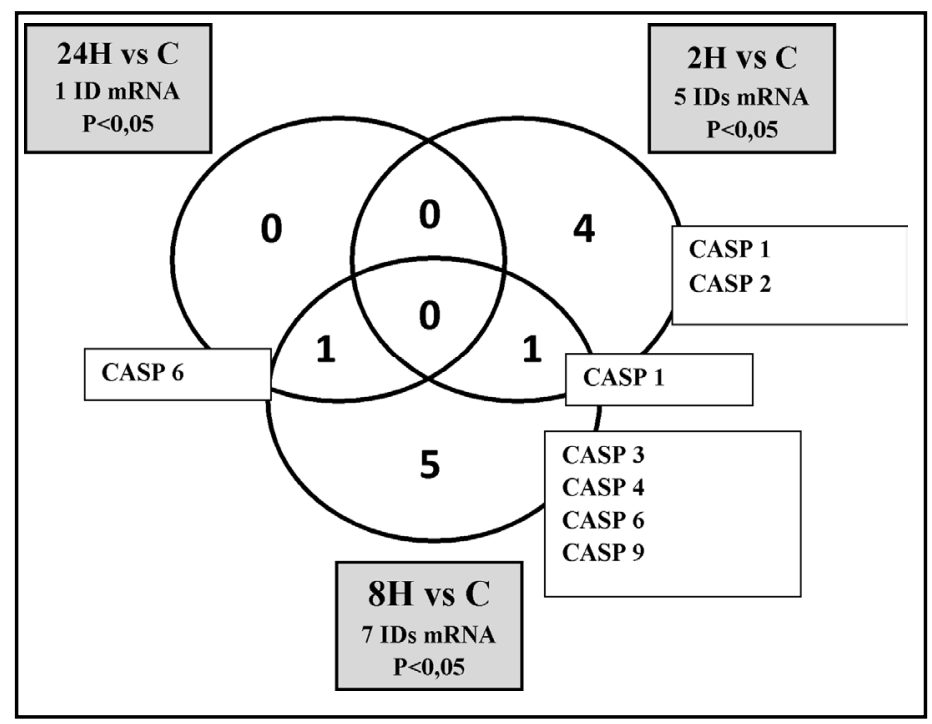

mRNA IDs were observed. After 24hour incubation with adalimumab, only 1 differentiating mRNA ID for caspase- 6 was observed, compared to the control sample, common for $8 \mathrm{H}$ and $24 \mathrm{H}$. No mRNA ID that would be common for all tested groups of fibroblasts was observed.

\section{Analysis of miRNA expression profile}

Statistical analysis of the results of miRNA microarray showed statistically significant $(p<0.05)$ change in the expression of 24 various miRNA molecules in NHDF, treated with adalimumab for: 2, 8 and 24h when compared with the control (Fig. 3).

\section{Bioinformatic analysis}

In order to identify which out of 24 differentiating miRNA molecules may regulate the expression of genes encoding caspases (CASP1, CASP2, CASP3, CASP4, CASP6 and CASP9), miRanda-mirSVR algorithm was used, based on microRNA.org database (http://www.microrna. org).

The analysis revealed 5 different miRNA molecules regulating the expression of: CASP2
Table 4. Quantitative changes in mRNA expression, with the indication of caspase family member and transcript name, upon challenging NHDF with adalimumab. Post-hoc Tukey's test results showing mRNA IDs differentiating studied groups legend for the Venn diagram (Fig. 2). FC - fold change

\begin{tabular}{|c|c|c|c|c|c|c|}
\hline Compared groups & Gene symbol & ID mRNA & $\begin{array}{l}\mathrm{p} \text {-value } \\
\text { correction }\end{array}$ & $\mathrm{p}$-value & \multicolumn{2}{|c|}{$\left(\log _{2}\right)$} \\
\hline \multicolumn{7}{|c|}{$2 \mathrm{H}$ vs $\mathrm{C}-5 \mathrm{mRNA}$} \\
\hline & CASP2 & 209812_x_at & 4,60E-02 & $2,95 \mathrm{E}-02$ & \multicolumn{2}{|c|}{-1.2782} \\
\hline & CASP1 & 211366_x_at & $6,60 \mathrm{E}-09$ & 1,06E-09 & \multicolumn{2}{|c|}{1.4062} \\
\hline \multirow[t]{2}{*}{$2 \mathrm{H}$ vs $\mathrm{C}$} & CASP1 & 211367_s_at & 8,03E-06 & $2,25 \mathrm{E}-06$ & \multicolumn{2}{|c|}{1.5849} \\
\hline & CASP1 & 211368_s_at & $1,96 \mathrm{E}-10$ & 7,82E-12 & \multicolumn{2}{|c|}{1.4671} \\
\hline \multirow{5}{*}{$\begin{array}{l}2 \mathrm{H} \text { vs } \mathrm{C} \\
\text { and } \\
8 \mathrm{H} \text { vs } \mathrm{C}\end{array}$} & & & & & $2 \mathrm{H}$ vsC & $8 \mathrm{H}$ vsC \\
\hline & CASP1 & 209970_x_at & $3,80 \mathrm{E}-10$ & $4,56 \mathrm{E}-11$ & 1.3233 & 1.1636 \\
\hline & \multicolumn{4}{|c|}{$8 \mathrm{H}$ vs $\mathrm{C}-7 \mathrm{mRNA}$} & & \\
\hline & CASP3 & 202763_at & $5,02 \mathrm{E}-08$ & $1,00 \mathrm{E}-08$ & \multicolumn{2}{|c|}{1.2272} \\
\hline & CASP9 & 203984_s_at & 0,003068 & $1,47 \mathrm{E}-03$ & \multicolumn{2}{|c|}{-1.2692} \\
\hline \multirow[t]{3}{*}{$\mathrm{H} 8$ vs $\mathrm{C}$} & CASP9 & 210775_x_at & 0,00365 & $1,90 \mathrm{E}-03$ & \multicolumn{2}{|c|}{-1.1922} \\
\hline & CASP6 & 211464_x_at & 1,15E-05 & 3,69E-06 & \multicolumn{2}{|c|}{-1.2842} \\
\hline & CASP4 & 213596_at & $8,24 \mathrm{E}-05$ & $2,96 \mathrm{E}-05$ & \multicolumn{2}{|c|}{1.4506} \\
\hline \multirow{2}{*}{$\begin{array}{l}2 \mathrm{H} \text { vs } \mathrm{C} \\
\text { and } \\
8 \mathrm{H} \text { vs } \mathrm{C}\end{array}$} & CASP1 & & $3,80 \mathrm{E}-10$ & $4,56 \mathrm{E}-11$ & $2 \mathrm{H}$ vsC & $8 \mathrm{H}$ vsC \\
\hline & & \multicolumn{2}{|l|}{ 209970_x_at } & & 1.3233 & 1.1636 \\
\hline & & & & & $8 \mathrm{H}$ vsC & $24 \mathrm{H}$ vsC \\
\hline $\begin{array}{l}\text { and } \\
24 \mathrm{H} \text { vs } \mathrm{C}\end{array}$ & CASP6 & 209790_s_at & 7,01E-08 & $1,68 \mathrm{E}-08$ & -1.3559 & 1.1529 \\
\hline \multicolumn{7}{|c|}{$24 \mathrm{H}$ vs $\mathrm{C}-1 \mathrm{mRNA}$} \\
\hline $\begin{array}{l}8 \mathrm{H} \text { vs } \mathrm{C} \\
\text { and }\end{array}$ & & & & & $\mathrm{H} 8 \mathrm{vsC}$ & $\mathrm{H} 24$ vsC \\
\hline $24 \mathrm{H}$ vs C & CASP6 & 209790_s_at & 7,01E-08 & 1,68E-08 & -1.3559 & 1.1529 \\
\hline
\end{tabular}
(three miRNAs), CASP3 (two miRNAs) and CASP6 (one miRNA) (Table 5). 
Fig. 3. The Venn diagram showing miRNAscharacteristic for transcriptomes of NHDF exposed to adalimumab in vitro in comparison to control. C=control, $2 \mathrm{H}, 8 \mathrm{H}$, $24 \mathrm{H}$ represent respectively: $2 \mathrm{~h}, 8 \mathrm{~h}$, and $24 \mathrm{~h}$ incubation time with adalimumab. The statistical evaluation was performed with the use of the post-hoc - Tukey's test.

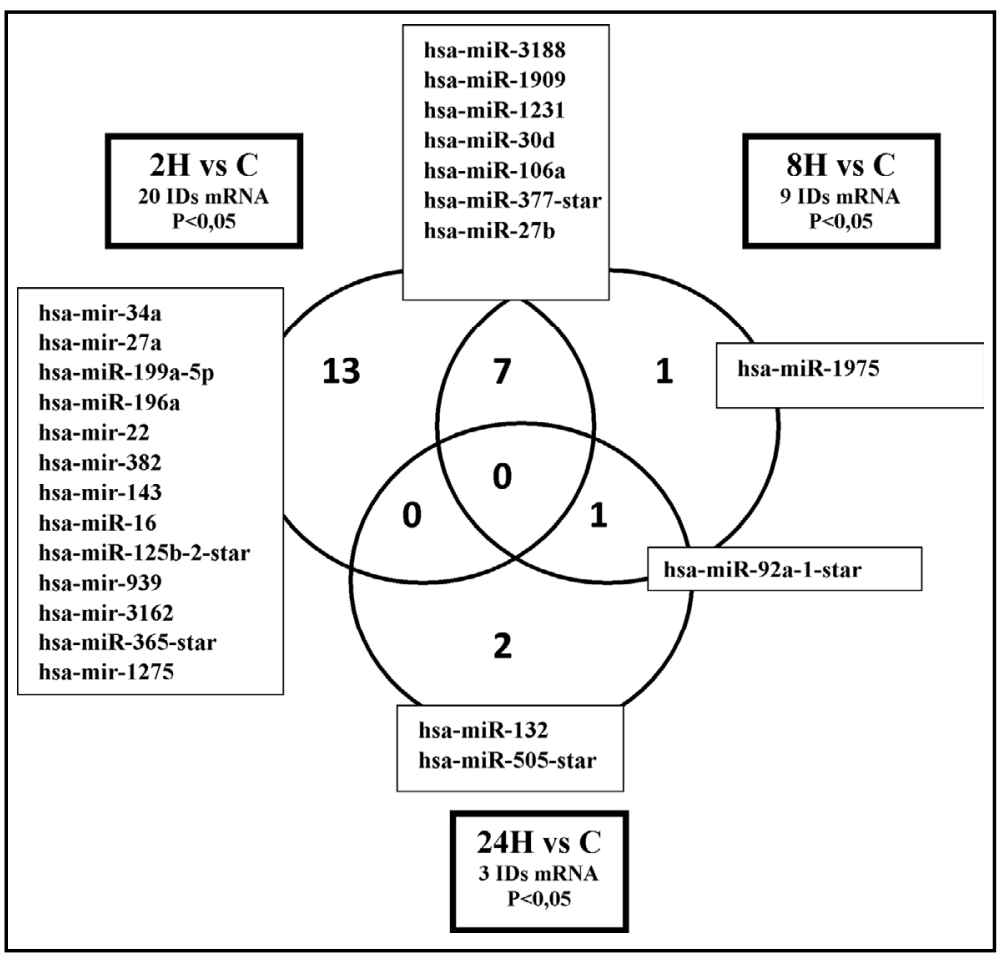

Table 5. Changes in the expression of CASP2, CASP3, CASP 6 genes and miRNAs capable of regulating expression of these genes in fibroblasts exposed to adalimumab for 2,8 and $24 \mathrm{~h}$, when compared to the control sample

\begin{tabular}{|c|c|c|c|c|c|c|c|c|c|c|c|c|c|c|c|c|c|c|c|c|}
\hline \multirow{2}{*}{$\begin{array}{l}\text { Gene } \\
\text { symbol } \\
\text { Exposure } \\
\text { time }\end{array}$} & \multicolumn{2}{|c|}{$\begin{array}{c}\text { CASP 2 } \\
\text { 209812_x_at }\end{array}$} & \multicolumn{2}{|c|}{ hsa-mir-34a } & \multicolumn{2}{|c|}{ hsa-mir-377 } & \multicolumn{2}{|c|}{ hsa-mir-106a } & \multicolumn{2}{|c|}{$\begin{array}{c}\text { CASP 3 } \\
\text { 202763_at }\end{array}$} & \multicolumn{2}{|c|}{$\begin{array}{l}\text { hsa-mir- } \\
\text { 30d }\end{array}$} & \multicolumn{2}{|c|}{$\begin{array}{c}\text { hsa-mir- } \\
382\end{array}$} & \multicolumn{2}{|c|}{$\begin{array}{c}\text { CASP 6 } \\
\text { 209790_s_at }\end{array}$} & \multicolumn{2}{|c|}{$\begin{array}{c}\text { CASP } 6 \\
\text { 211464_x_at }\end{array}$} & \multicolumn{2}{|c|}{ hsa-mir-106a } \\
\hline & $\begin{array}{c}\mathrm{p}- \\
\text { value }\end{array}$ & $\begin{array}{c}\mathrm{FC} \\
\left(\log _{2}\right)\end{array}$ & $\begin{array}{c}\mathrm{p}- \\
\text { value }\end{array}$ & $\begin{array}{c}\mathrm{FC} \\
\left(\log _{2}\right)\end{array}$ & $\begin{array}{c}\mathrm{p}- \\
\text { value }\end{array}$ & $\begin{array}{c}\mathrm{FC} \\
\left(\log _{2}\right)\end{array}$ & $\begin{array}{c}\mathrm{p}- \\
\text { value }\end{array}$ & $\begin{array}{c}\mathrm{FC} \\
\left(\log _{2}\right)\end{array}$ & $\begin{array}{c}\mathrm{p}- \\
\text { value }\end{array}$ & $\begin{array}{c}\mathrm{FC} \\
\left(\log _{2}\right)\end{array}$ & $\begin{array}{c}\mathrm{p}- \\
\text { value }\end{array}$ & $\begin{array}{c}\mathrm{FC} \\
\left(\log _{2}\right)\end{array}$ & $\begin{array}{c}\mathrm{p}- \\
\text { value }\end{array}$ & $\begin{array}{c}\mathrm{FC} \\
\left(\log _{2}\right)\end{array}$ & $\begin{array}{c}\mathrm{p}- \\
\text { value }\end{array}$ & $\begin{array}{c}\mathrm{FC} \\
\left(\log _{2}\right)\end{array}$ & $\begin{array}{c}\mathrm{p}- \\
\text { value }\end{array}$ & $\begin{array}{c}\mathrm{FC} \\
\left(\log _{2}\right)\end{array}$ & $\begin{array}{c}\mathrm{p}- \\
\text { value }\end{array}$ & $\begin{array}{c}\mathrm{FC} \\
\left(\log _{2}\right)\end{array}$ \\
\hline $2 \mathrm{H}$ & 0.029 & $\downarrow 1.278$ & 0.043 & $\uparrow 6.52$ & 0.023 & $\uparrow 2.7$ & 0.001 & $\uparrow 2.09$ & & & 0.015 & $\uparrow 2.19$ & 0.009 & $\uparrow 2.82$ & & & & & 0.001 & $\uparrow 2.09$ \\
\hline $8 \mathrm{H}$ & & & & & 0.013 & $\uparrow 2.32$ & 0.007 & $\uparrow 2.45$ & $\begin{array}{c}1,00 \mathrm{E}- \\
08\end{array}$ & $\uparrow 1.227$ & 0.045 & $\uparrow 2.55$ & & & $\begin{array}{c}1,68 \mathrm{E}- \\
08\end{array}$ & $\downarrow 1.356$ & $\begin{array}{c}3,69 \mathrm{E}- \\
06\end{array}$ & $\downarrow 1.284$ & 0.007 & $\uparrow 2.45$ \\
\hline $24 \mathrm{H}$ & & & & & & & & & & & & & & & $\begin{array}{c}1,68 \mathrm{E}- \\
08\end{array}$ & $\uparrow 1.152$ & & & & \\
\hline mirSVR & & & $\downarrow 0.2$ & 232 & $\downarrow 0.3$ & 218 & $\downarrow 0.4$ & 468 & & & $\downarrow 0.3$ & 918 & $\downarrow 1.2$ & 289 & & & & & & 1209 \\
\hline
\end{tabular}

2 hours after adalimumab administration, 3 miRNAs showed overexpression: hsamir-34a, hsa-mir-377, hsa-mir-106a potentially capable of regulating expression of gene encoding caspase-2. At the same time, lower expression of the tested gene was observed. After 8hours, expression of the gene encoding caspase- 2 reached the level observed in the control.

The hsa-mir-106a molecule also shows potential capability to regulate caspase-6. Increased expression of hsa-mir-106aco-occurred with the lower expression of CASP6 after $8 \mathrm{~h}$ of incubation with adalimumab. The return of miRNA expression to the level observed in the control after $24 \mathrm{~h}$ after administration of the drug corresponded to the increase in the expression of the caspase- 6 encoding gene.

One miRNA molecule was determined for caspase-3 -hsa-mir-30d. Expression of both CASP3 gene and hsa-mir-30d was down regulated in cells treated with adalimumab for $8 \mathrm{~h}$ comparing to control cells. 
Table 6. Result of the post hoc Tukey's test for CASP6 in the tested groups $(2 \mathrm{H}, 8 \mathrm{H}, 24 \mathrm{H})$, compared to the control sample

\begin{tabular}{ccccc}
\hline Time & $2 \mathrm{H}$ & $8 \mathrm{H}$ & $24 \mathrm{H}$ \\
\hline $\mathrm{p}$-Value & $\mathrm{NS}$ & 0,002748 & 0,047468 \\
\hline
\end{tabular}

Fig. 4. The expression profile of CASP6 gene in normal human dermal fibroblasts (NHDF), depending on the time of exposure to adalimumab in vitro. $\mathrm{C}=$ control (NHDF not treated with adalimumab), $2 \mathrm{H}, 8 \mathrm{H}, 24 \mathrm{H}$ represent respectively: 2 h, 8 h, and 24 $\mathrm{h}$ incubation time with adalimumab. The expression level of caspase- 6 mRNA was determined by qRT-PCR.

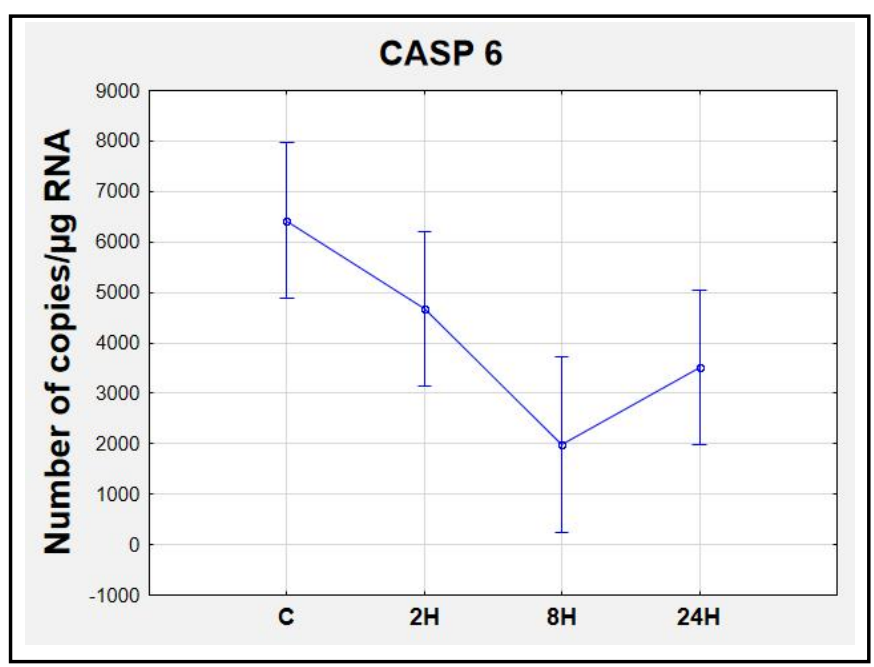

Fig. 5. Expression of gene encoding caspase- 6 in the psoriatic patients' blood. The blood was collected before$(0 \mathrm{H})$ and 2 hours $(2 \mathrm{H})$ after adalimumab administration. The expression level of caspase- 6 mRNA was determined by qRT-PCR.

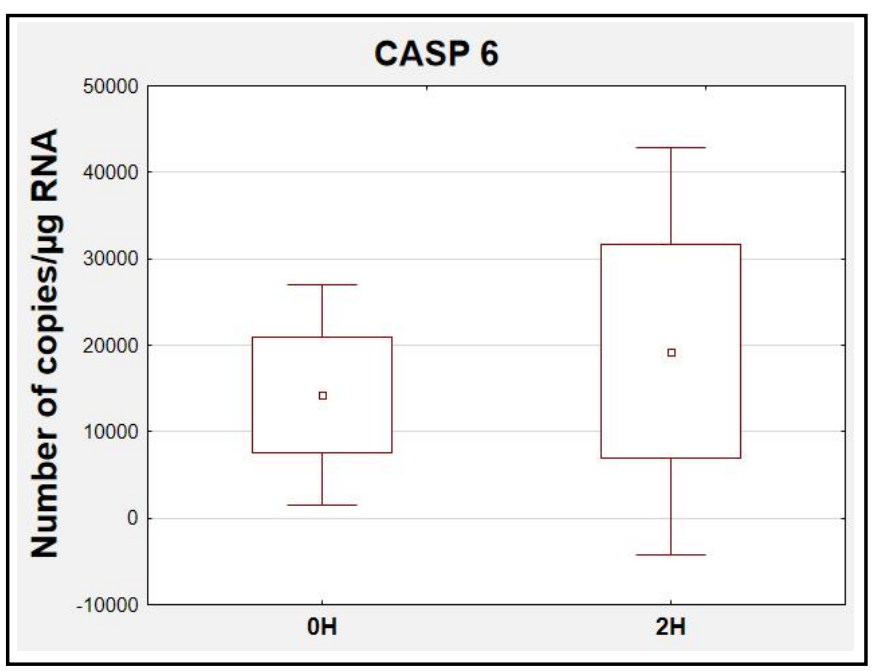

Validation of the oligonucleotide microarray results

The last stage of the analysis was the validation of the microarray results with the use of qRT-PCR method. Only CASP6 gene was analyzed, because during the microarray experiment statistically significant changes in the expression profile of this gene were observed in the groups under study $(2 \mathrm{H}, 8 \mathrm{H}, 24 \mathrm{H})$ when compared to the control. Moreover, it was shown that CASP6 expression might be regulated by hsa-mir-106a molecule. The results showed a statistically significant difference in the expression of the tested gene in the cells treated for 8 and 24 hours with adalimumab, when compared to the control sample (Table 6, Fig. 4). 


\section{Cellular Physiology Cell Physiol Biochem 2018;50:525-537 \begin{tabular}{c|c|c|c|} 
DOI: 10.1159/000494166 & O 2018 The Author(s). Published by S. Karger AG, Basel \\
www.karger.com/cpb
\end{tabular} \\ Wcisło-Dziadecka et al.: Therapy-Induced Changes of Caspase Expression}

\section{Analysis of the expression of gene encoding caspase-6 in patients' blood}

The analysis did not show any statistically significant differences in the expression of gene encoding caspase- 6 in the patients' blood before and 2 hours after the anti-TNF drug administration (Fig. 5). The expression level of caspase- 6 mRNA was determined by qRTPCR as described in the method section.

\section{Discussion}

The anti-TNF therapy constitutes one of the most effective therapies of the proinflammatory diseases. It is mainly used in the treatment of serious forms of psoriasis and other pro-inflammatory diseases, as well as in those cases where standard anti-inflammatory therapies are ineffective. adalimumab, an anti-TNF drug, is a fully-humanized monoclonal antibody. The adalimumab and other anti-TNF drugs are highly effective, however, they cause many side effects [30]. Moreover, some patients treated with anti-TNF drugs do not respond to the therapy. Many of them show the primary non-response (PNR), whereas some others show a loss of response to treatment (LOR) after some time of effective therapy [31]. Reduced response to anti-TNF treatment may be caused by polymorphism in genes encoding proteins associated with apoptosis, such as caspase-9 or NLRP3 gene encoding one of the proteins that constitutes an element of inflammasome [36]. Hence, molecular markers, which could indicate decreased efficiency of treatment before occurrence of symptoms, are being sought.

This work focused on the determination of expression profile of genes encoding caspases and miRNA in dermal fibroblasts exposed for adalimumab for 2-, 8- and 24h. The oligonucleotide microarray technology facilitates simultaneous evaluation of expression of many genes, including those encoding caspases and miRNA molecules. Evaluation of the gene expression at various intervals since drug administration enabled full analysis and more accurate identification of the mechanism responsible for changes.

The results obtained in the course of the study showed that adalimumab affected the transcription activity of genes encoding caspases in dermal fibroblasts, which may suggest that genes encoding caspases participate in cell response to the administered drug. Changes in the expression profile of genes encoding caspases observed in fibroblasts depended on time of exposure to tested drug. adalimumab showed its activity as early as $2 \mathrm{~h}$ after its administration, however, the greatest variations in the expression profile of the tested genes was observed after 8 hours of incubation, when compared to the control sample. After $24 \mathrm{~h}$, the expression profile of genes encoding caspases returns almost to the pretreatment level, or level observed in the control cells. This may be indicative of adaptive mechanisms triggering in cells, in response to the drug treatment, or simply represent the end of the response. However, it is also possible that the effect may be connected with the reduced concentration of the drug in the medium due to the fact that drug molecules adsorb to the plate surface.

Expression of genes is strictly regulated on various levels, including numerous epigenetic mechanisms. Initial studies of Carmen Castro-Villegas and colleagues [37] proved that circulating miRNAs could be used as diagnostic markers in monitoring anti TNF drug therapies in patients with rheumatoid arthritis. The bioinformatic analysis showed several possible interactions between differentiating mRNAs and miRNAs described in this paper. Hsa-mir-34a, hsa-mir-377, hsa-mir-106amay be responsible for changes in the expression of gene encoding caspase- 2 , whereas hsa-mir-30d and hsa-mir-106a molecules may regulate activity of genes encoding: caspase- 3 and caspase- 6 , respectively, however, this mechanism must be further examined. None of the differentiating miRNAs found in this study may interact with mRNA of genes encoding caspases: $-1,-4$ and -9 .

Validation of the results of the oligonucleotide microarray with the use of qRT-PCR confirmed the effects of adalimumab on the expression of gene encoding caspase- 6 in NHDF 


\section{Cellular Physiology Cell Physiol Biochem 2018;50:525-537 \begin{tabular}{ll|l} 
DOI: 10.1159/000494166 & O 2018 The Author(s). Published by S. Karger AG, Basel \\
www.karger.com/cpb
\end{tabular} \\ Wcisło-Dziadecka et al.: Therapy-Induced Changes of Caspase Expression}

cell line.Caspase- 6 is one of the effector caspases in apoptosis. It is responsible, among others, for inactivation of nuclear structural proteins - lamins, which leads to the condensation of chromatin and fragmentation of cell nucleus [38]. Two isoforms of caspase- 6 have been identified, which occur as a result of an alternative splicing of the gene [39]. Caspase- 6 expression and activity increases early after excitotoxic event in neurons. With regard to the foregoing, it is assumed that caspase- 6 may also play an initiating role in an apoptotic cascade [40].

Expression of gene encoding caspase- 6 in dermal fibroblasts changes with the time of fibroblasts incubation with adalimumab. The mechanism underlying these changes may be connected with miRNA molecules. For the analysis 19 miRNA molecules were chosen from the microRNA.org (http://www.microrna.org) database. According to miRandamirSVR algorithm - may be capable of regulating the gene encoding caspase-6, among them being Hsa-mir-106a molecule. Hsa-mir-106a plays either the role of neoplastic process suppressor, or an oncogene, depending on tissue type [41-43]. The studies showed that the molecule is capable of promoting apoptosis [44].

The mirSVR software interaction analysis for hsa-mir-106a and caspase- 6 indicates poor consensus for interaction between target mRNA and miRNA molecule. However, the obtained results show certain correlation between the direction of expression of both molecules. The correlation between the direction of expression of the gene encoding caspase- 6 and hsamir-106 gene may indicate the regulating role of this miRNA, however this thesis requires further studies. The studies revealed that adalimumab did not affect the profile of caspase- 6 expression in psoriatic patients' blood $2 \mathrm{~h}$ after drug administration.

In this study for the first time expression profile of genes encoding caspases and miRNAs that may regulate their activity under anti-TNF treatment were assessed. Summing up: the obtained results initially confirm that caspases may participate in cell response to the administered drug, thus, in the future they may be used as molecular markers supplementing monitoring the therapy with the use of an anti-TNF drugs, including adalimumab. It is likely that the mechanism responsible for the change of the expression profile of genes encoding caspases-2,-3 and -6 may be connected with microRNA molecules. Increased expression of genes encoding specific caspases may induce inflammatory processes, as well as trigger apoptosis. Furthermore, the proapoptotic activity of caspases may have been enhanced by miRNA molecules, which exhibit proapoptotic function. The overexpression of such miRNAs was observed in this study.

\section{Acknowledgements}

MJŁ kindly acknowledges the support from NCN grant \#: 2016/21/B/NZ1/02812, the supported by LE STUDIUM Institute for Advanced Studies (region Centre-Val de Loire, France) through its Smart Loire Valley General Program, co-funded by the Marie Sklodowska-Curie Actions, grant \# 665790. CG kindly acknowledges the support by the FUI16 grant 'GLYCOSKIN I' from the Pole of competitiveness Cosmetic Valley, the French Ministry for Industry and the region Centre-Val de Loire (BPI n¹31 1004 F/ Region CVL n²014-00090160).

\section{Disclosure Statement}

The authors declare that no conflicts of interest exist. 


\section{Cellular Physiology Cell Physiol Biochem 2018;50:525-537 \begin{tabular}{l|l|l} 
and Biochemistry $10.1159 / 000494166$ & (c) 2018 The Author(s). Published by S. Karger AG, Basel \\
www.karger.com/cpb
\end{tabular} \\ Wublished online: 11 Octo-Dziadecka et al.: Therapy-Induced Changes of Caspase Expression}

\section{References}

1 Los M, van de Craen M, Penning CL, Schenk H, Westendorp M, Baeuerle PA, Dröge W, Krammer PH, Fiers W, Schulze-Osthoff K: Requirement of an ICE/Ced-3 protease for Fas/Apo-1-1mediated apoptosis. Nature 1995;371:81-83.

2 Los M, Wesselborg S, Schulze-Osthoff K: The role of caspases in development, immunity, and apoptotic signal transduction: lessons from knockout mice. Immunity 1999;10:629-639.

-3 Sollberger G, Strittmatter GE, Kistowska M, French LE, Beer HD: Caspase-4 is required for activation of inflammasomes. J Immunol 2012;188:1992-2000.

-4 Hauff K, Zamzow C, Law WJ, De Melo J, Kennedy K, Los M: Peptide-based approaches to treat asthma, arthritis, other autoimmune diseases and pathologies of the central nervous system. Arch Immunol Ther Exp 2005;53:308-320.

5 Martin SJ, Henry CM, Cullen SP: A perspective on mammalian caspases as positive and negative regulators of inflammation. Mol Cell 2012;46:387-397.

6 Vande Walle L, Lamkanfi M: Inflammasomes: caspase-1-activating platforms with critical roles in host defense. Front Microbiol 2011;2:3.

7 Lamkanfi M, Festjens N, Declercq W, Vanden Berghe T, Vandenabeele P: Caspases in cell survival, proliferation and differentiation. Cell Death Differ 2007;14:44-55.

8 Li J, Yuan J: Caspases in apoptosis and beyond. Oncogene 2008;27:6194-6206.

-9 Los M, Stroh C, Janicke RU, Engels IH, Schulze-Osthoff K: Caspases: more than just killers? Trends Immunol 2001;22:31-34.

10 Mcllwain DR, Berger T, Mak TW: Caspase functions in cell death and disease. Cold Spring Harb Perspect Biol 2013;5:a008656.

11 Miao EA, Rajan JV, Aderem A: Caspase-1-induced pyroptotic cell death. Immunol Rev 2011;243:206-214.

12 Chaabane W, User SD, El-Gazzah M, Jaksik R, Sajjadi E, Rzeszowska-Wolny J, Los MJ: Autophagy, apoptosis, mitoptosis and necrosis: interdependence between those pathways and effects on cancer. Arch Immunol Ther Exp (Warsz) 2013;61:43-58.

$>13$ Mokarram P, Albokashy M, Zarghooni M, Moosavi MA, Sepehri Z, Chen QM, Hudecki A, Sargazi A, Alizadeh J, Moghadam AR, Hashemi M, Movassagh H, Klonisch T, Owji AA, Los MJ, Ghavami S: New frontiers in the treatment of colorectal cancer: Autophagy and the unfolded protein response as promising targets. Autophagy 2017;13:781-819.

14 Polewska J: Autofagia - mechanizm molekularny, apoptoza i nowotwory. Postepy Hig Med Dosw (online) 2012;66:921-936.

15 Moosavi MA, Sharifi M, Ghafary SM, Mohammadalipour Z, Khataee A, Rahmati M, Hajjaran S, Los MJ, Klonisch T, Ghavami S: Photodynamic N-TiO2 Nanoparticle Treatment Induces Controlled ROS-mediated Autophagy and Terminal Differentiation of Leukemia Cells. Sci Rep 2016;6:34413.

16 Shalini S, Dorstyn L, Dawar S, Kumar S: Old, new and emerging functions of caspases. Cell Death Differ 2015;22:526-539.

17 MacKenzie SH, Schipper JL, Clark AC: The potential for caspases in drug discovery. Curr Opin Drug Discov Devel 2010;13:568-576.

18 Lavrik IN, Golks A, Krammer PH: Caspases: pharmacological manipulation of cell death. J Clin Invest 2005;115:2665-2672.

19 de Zoete MR, Palm NW, Zhu S, Flavell RA: Inflammasomes. Cold Spring Harb Perspect Biol 2014;6:a016287.

$\checkmark 20$ Martinon F, Tschopp J: Inflammatory caspases and inflammasomes: master switches of inflammation. Cell Death Differ 2007;14:10-22.

21 Park HH: Structural features of caspase-activating complexes. Int J Mol Sci 2012;13:4807-4818.

22 Ghavami S, Hashemi M, Ande SR, Yeganeh B, Xiao W, Eshraghi M, Bus CJ, Kadkhoda K, Wiechec E, Halayko AJ, Los M: Apoptosis and cancer: mutations within caspase genes. J Med Genet 2009;46:497-510.

23 Salskov-Iversen ML, Johansen C, Kragballe, K, Iversen L: Caspase-5 expression is upregulated in lesional psoriatic skin. J Invest Dermatol 2011;131:670-676.

24 Szczeblowska D, Hebzda A, Wojtuń S: Choroby autoimmunizacyjne w praktyce lekarskiej. Pediatr Med Rodz 2011;7:218-222.

25 An J, Li T, Dong Y, Li Z, Huo J: Terminalia Chebulanin Attenuates Psoriatic Skin Lesion via Regulation of Heme Oxygenase-1. Cell Physiol Biochem 2016;39:531-543. 


\section{Cellular Physiology Cell Physiol Biochem 2018;50:525-537

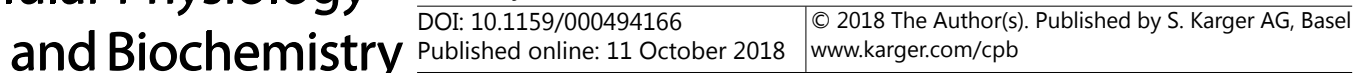 \\ Published online: 11 Octo}

26 Hu XP, Xie Q Chen CF, Zhang W, Yu B: Let-7a Inhibits T-Cell Proliferation and IFN- $\gamma$ Secretion by DownRegulating STAT3 Expression in Patients with Psoriasis.Cell Physiol Biochem 2017;42:115-125.

27 Liu HQ, Wang YM, Li WF, Li C, Jiang ZH, Bao J, Wei JF, Jin HT, Wang AP: Anti-Psoriasis Effects and Mechanisms of A-(8-Quinolinoxy) ZincPhthalocyanine-Mediated Photodynamic Therapy. Cell Physiol Biochemn 2017;44:200-214.

-28 Bradley JR: TNF-mediated inflammatory disease. J Pathol 2008;214:149-160.

29 Neneman A, Adamski Z: Aspekty kliniczne i epidemiologiczne zaburzeń ogólnoustrojowych u chorych na łuszczycę. Forum Med Rodz 2009;3:447-453.

30 Romańska-Gocka K: Farmakoterapia łuszczycy. Farm Pol 2009;65:647-654.

-31 Roda G, Jharap B, Neeraj N, Colombel JF: Loss of Response to Anti-TNFs: Definition, Epidemiology, and Management. Clin Transl Gastroenterol 2016;7:e135.

32 Budzyński M, Grenda A, Filip A: Krążące mikroRNA - nowa klasa biomarkerów diagnostycznoprognostycznych w przebiegu chorób nowotworowych. Postepy Biol Komorki 2014;41:173-208.

-33 Fic P, Kowalczuk K, Grabarska A., Stepulak A: Mikro-RNA - nowe szanse diagnostyczne w chorobie niedokrwiennej i zawale serca. Postepy Hig Med Dosw (online) 2014;68:410-418.

-34 Grenda A, Budzyński M, Filip A: Biogeneza cząsteczek mikroRNA oraz ich znaczenie w powstawaniu i przebiegu wybranych zaburzeń hematologicznych. Postepy Hig Med Dosw (online) 2013;67:174-185.

- 35 Jain MV, Shareef A, Likus W, Cieslar-Pobuda A, Ghavami S, Los MJ: Inhibition of miR301 enhances Aktmediated cell proliferation by accumulation of PTEN in nucleus and its effects on cell-cycle regulatory proteins. Oncotarget 2016;7:20953-20965.

-36 Hlavaty T, Pierik M, Henckaerts L, Ferrante M, Joossens S, van Schuerbeek N, Noman M, Rutgeerts P, Vermeire S: Polymorphisms in apoptosis genes predict response to infliximab therapy in luminal and fistulizing Crohn's disease. Aliment Pharmacol Ther 2005;22:613-626.

-37 Castro-Villegas C, Perez-Sanchez C, Escudero A, Filipescu I, Verdu M, Ruiz-Limon P, Aguirre MA, JimenezGomez Y, Font P, Rodriguez-Ariza A, Peinado JR, Collantes-Estevez E, Gonzalez-Conejero R, Martinez C, Barbarroja N, Lopez-Pedrera C: Circulating miRNAs as potential biomarkers of therapy effectiveness in rheumatoid arthritis patients treated with anti-TNFalpha. Arthritis Res Ther 2015;17:49.

-38 Ruchaud S, Korfali N, Villa P, Kottke TJ, Dingwall C, Kaufmann SH, Earnshaw WC: Caspase-6 gene disruption reveals a requirement for lamin A cleavage in apoptotic chromatin condensation. EMBO J 2002;21:19671977.

-39 Lee AW, Champagne N, Wang X, Su XD, Goodyer C, Leblanc AC: Alternatively spliced caspase-6B isoform inhibits the activation of caspase-6A. J Biol Chem 2010;285:31974-31984.

40 Girling KD, Demers MJ, Laine J, Zhang S, Wang YT, Graham RK: Activation of caspase-6 and cleavage of caspase- 6 substrates is an early event in NMDA receptor-mediated excitotoxicity. J Neurosci Res 2018;96:391-406.

41 Li P, Xu Q, Zhang D, Li X, Han L, Lei J, Duan W, Ma Q, Wu Z, Wang Z: Upregulated miR-106a plays an oncogenic role in pancreatic cancer. FEBS Lett 2014;588:705-712.

-42 Wang Z, Wang B, Shi Y, Xu C, Xiao HL, Ma LN, Xu SL, Yang L, Wang QL, Dang WQ, Cui W, Yu SC, Ping YF, Cui YH, Kung HF, Qian C, Zhang X, Bian XW: Oncogenic miR-20a and miR-106a enhance the invasiveness of human glioma stem cells by directly targeting TIMP-2. Oncogene 2015;34:1407-1419.

43 Yang G, Zhang R, Chen X, Mu Y, Ai J, Shi C, Liu Y, Shi C, Sun L, Rainov NG, Li H, Yang B, Zhao S: MiR-106a inhibits glioma cell growth by targeting E2F1 independent of p53 status. J Mol Med (Berl) 2011;89:10371050.

44 Zhi F, Zhou G, Shao N, Xia X, Shi Y, Wang Q Zhang Y, Wang R, Xue L, Wang S, Wu S, Peng, Y, Yang Y: miR106a-5p inhibits the proliferation and migration of astrocytoma cells and promotes apoptosis by targeting FASTK. PLoS One 2013;8:e72390. 